\title{
ECOLOGICAL STATE ASSESSMENT OF RECREATIONAL AREAS IN NIZHNY NOVGOROD ON HEAVY METAL SOIL POLLUTION AND BIOINDICATION INDICATORS OF BETULA PENDULA ROTH LEAVES
}

(C) 2020

Sidorenko Mikhail Vladimirovich, candidate of biological sciences, associate professor of Ecology Department

Yunina Valentina Petrovna, senior lecturer of Ecology Department

Erofeeva Elena Aleksandrovna, doctor of biological sciences, associate professor of Ecology Department

Savinov Aleksandr Borisovich, candidate of biological sciences, associate professor of Ecology Department

Kuznetsov Maksim Dmitrievich, postgraduate student of Ecology Department

Novozhilov Denis Alekseevich, postgraduate student of Ecology Department

National Research Lobachevsky State University of Nizhny Novgorod (Nizhny Novgorod, Russian Federation)

Abstract. In this paper the ecological state of recreational areas in Nizhny Novgorod was assessed by the level of soil contamination with heavy metals (HM) and the values of bioindication indicators of the birch (Betula pendula Roth). The objects of the study were 4 recreational areas. The forest park «Shelokovsky Farm» located far from pollution sources was chosen as a control site. The excess of normative indicators (in multiplicities of normative indicators) on gross content of HM was observed in soils only for nickel: in the park «Switzerland» in 1,3 times, in «Raspberry Ridge» - in 2,3 times. The soils with the pollution category «moderately dangerous» were the most polluted by HM according to the total indicator of pollution: in the protected area «Crimson Ridge» and in the park «Oaks». Bioindication indicators of a birch leaf deviated from the conventional norm in a number of studied areas. The quality of the environment, estimated by fluctuating asymmetry of birch leaves in «Shelokovsky Farm» and the park «Oaks», correspond to 2 points (a slight deviation from the norm), in the Park «Switzerland» - to 3 points (the average deviation from the norm), and in «Crimson Ridge» - to 4 points (a significant deviation from the norm). In the two most contaminated sites («Oaks» and «Crimson Ridge»), a decrease of chlorophyll content in birch leaves relative to the control («Shelokovsky Farm») was observed.

Keywords: Nizhny Novgorod; recreational zone; soil; heavy metals; copper; cobalt; nickel; lead; zinc; manganese; cadmium; chromium; iron; mercury; total indicator of soil contamination with heavy metals; Betula pendula Roth; leaf; fluctuating asymmetry; chlorophylls; carotenoids; bioindication.

$* * *$

УДК 582.29

DOI 10.24411/2309-4370-2020-11115

Статья поступила в редакцию 15.01.2020

\section{ЭКОЛОГИЯ И РАСПРОСТРАНЕНИЕ РЕДКИХ ВИДОВ ЛИШАЙНИКОВ ЧУВАШСКОГО ПРИСУРЬЯ}

(C) 2020

\author{
Синичкин Евгений Аркадьевич, научный сотрудник \\ Чебоксарский филиал Главного ботанического сада им. Н.В. Цицина РАН \\ (2. Чебоксары, Российская Федераџия)
}

Богданов Геннадий Алексеевич, старший научный сотрудник

Государственный природный заповедник «Большая Кокшага» (г. Йошкар-Ола, Российская Федеращия)

Димитриев Александр Вениаминович, кандидат биологических наук, директор

Чебоксарский филиал Главного ботанического сада им. Н.В. Цицина РАН

(2. Чебоксары, Российская Федераџия)

Аннотаиия. В статье приводятся данные о 20 новых и редких видах лишайников, обнаруженных на тер-
ритории Чувашского Присурья. 10 видов являются новыми для Чувашской Республики, 5 видов - новые для
Приволжской возвышенности. Выявленные виды лишайников являются индикаторами старовозрастных, не-
нарушенных и малонарушенных лесов, которые сохранились на особо охраняемых природных территориях.
На территории Национального парка «Чаваш вармане» отмечено 18 редких видов, в Государственном при-
родном заповеднике «Присурский» - 8 видов. Для каждого вида указываются географические координаты,
особенности распространения в соседних регионах, эколого-субстратная и фитоценотическая приурочен-
ность, возрастное состояние. Уточнены сведения по экологии и распространению редких видов лишайников.
18 видов лишайников (Bryoria nadvornikiana, Br. trichodes, Cetrelia olivetorum, Cresponea chloroconia, Evernia
divaricata, Heterodermia speciosa, Leptogium cyanescens, L. saturninum, Nephroma parile, Scytinium subtile,
Sc. teretiusculum, Sc. tenuissimum, Usnea dasopoga, Us. florida, Us. subfloridana, Ramalina thrausta, R. sinensis,
Хanthoтепdoza ulophyllodes) предложены в новое издание Красной книги Чувашской Республики со статусом
III - редкие виды. 2 вида лишайников (Cetraria ericetorum, Lobaria риlтопаria) отнесены к категории II - уяз-
вимые виды, сокращающиеся в численности.
Ключевые слова: лишайники; лихенофлора; редкие виды; растительные сообщества; лес; сосновые леса;
липовые леса; осиновые леса; березовые леса; ареал; Чувашское Присурье; Государственный природный за-
поведник «Присурский»; Национальный парк «Чаваш вармане»; Алатырский район; Ибресинский район;
особо охраняемая природная территория; Красная книга; Чувашская Республика. 


\section{Введение}

Чувашское Присурье является уникальной природной территорией, где сохранились старовозрастные хвойные, хвойно-широколиственные и пойменные леса.

По природному районированию В.Г. Папченкова, А.В. Димитриева, основанному на бассейновом принципе, территория Чувашского Присурья относится к природному району Присурье, который захватывает лесистое правобережье реки Сура. Поверхность района представляет собой холмистую равнину, постепенно опускающуюся к долине р. Суры, имеющей низкий и пологий склон и хорошо выраженную широкую пойму с многочисленными песчаными гривами и старицами между ними [1].

Чувашское Присурье упоминается в работе А.Д. Плетневой-Соколовой как Присурский лесной массив [2]. Согласно физико-географическому районированию А.В. Ступишина, указанная территория почти полностью представлена Засурским полесским районом смешанных лесов [3]. Современное ботанико-географическое районирование относит Чувашское Присурье к 2 районам: Алатырский присурский район южной полосы хвойных и смешанных лесов и Красночетайский присурский район широколиственных и смешанных лесов [4].

На территории Чувашского Присурья в настоящее время расположены особо охраняемые природные территории федерального и регионального значения: государственный природный заповедник «Присурский», национальный парк «Чаваш вармане», Государственный природный заказник «Пойма реки Сура», Государственный природный заказник «Кумашкинский», Государственный природный заказник «Бугуяновский», Памятник природы «Каенсар» и др. [5-7].

Ранее нами был опубликован ряд статей по лихенофлоре изучаемой территории [8-17]. В данной статье приведены сведения о новых и редких видах лишайников, обнаруженных на территории Ибресинского, Алатырского, Шемуршинского районов, в том числе на территории государственного природного заповедника «Присурский» и национального парка «Чаваш вармане».

Цель нашего исследования: изучение экологии и распространения редких видов лишайников Чувашского Присурья.

\section{Материалы и методы исследований}

В результате лихенологических исследований в 2011-2019 гг. были выявлены редкие виды лишайников, для которых нами указаны категории редкости согласно положению о Красной книге Чувашской Республики [18]. Для каждого вида указываются географические координаты, особенности распространения в соседних регионах, эколого-субстратная и фитоценотическая приуроченность [19; 20; 24], возрастное состояние, которое определялось по морфологическим признакам талломов [19; 21-23]. Список редких видов лишайников представлен в алфавитном порядке. Систематическое положение вида представлена по списку лихенофлоры России с учетом сводки по T.L. Esslinger [24; 25].

\section{Результаты и их обсуждение}

Bryoria nadvornikiana (Gyeln.) Brodo et D. Hawksw. - редкий для лихенофлоры Чувашской Республики.
Указан для республик Марий Эл [26] и Мордовия [27]. На территории Чувашии обнаружен в Заволжье Чувашской Республики (Чебоксарский район) [28; 29]. Произрастает высоко в кронах хвойных деревьев. Является индикатором старовозрастных, ненарушенных и малонарушенных лесов [30]. Как редкий вид занесен в Красную книгу Республики Татарстан [31] и в список редких и уязвимых видов растений и грибов Республики Мордовия [32].

Места находок: национальный парк «Чаваш вармане», Шемуршинский район, кв. 88 Баскакского участкового лесничества, на коре Tilia cordata Mill. липняк злаково-разнотравный, 5450,591' с.ш., $47^{\circ} 12,307^{\prime}$ в.Д., 04.07.2011 г.; кв. 75 Баскакского участкового лесничества, на ветках Picea abies (L.) H. Karst. в сообществе лишайников Evernia mesomorpha Nyl., E prunastri (L.) Ach., Parmelia sulcata Taylor, Pseudevernia furfuracea (L.) Zopf, Tuckermannopsis chlorophylla (Willd.) Hale, Usnea hirta (L.) We-

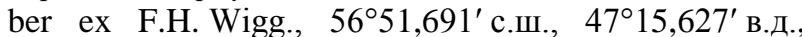
06.07.2011 г.

Bryoria trichodes (Michx.) Brodo et D. Hawksw. редкий вид для лихенофлоры Чувашской Республики. Раннее обнаружен на коре Pinus sylvestris L. во влажных сосново-еловых и сосновых лесах [33]. Находится за пределами своего ареала. Как редкий вид занесен в Красную книгу Республики Марий Эл [34].

Место находки: национальный парк «Чаваш вармане», Шемуршинский район, кв. 88 Баскакского участкового лесничества, на коре Tilia cordata, опушка липняка злаково-разнотравного, 54 50,793' с.ш., $47^{\circ} 13,989^{\prime}$ в.д., 02.08.2012 г.

Cetraria ericetorum Opiz - редкий ледниковый реликт на южной границе ареала. Отмечен на территории Республики Марий Эл и Нижегородской области [34; 35]. Занесен в Красную книгу Республики Мордовия [32]. На территории Чувашии обнаружен в 90х годах XX в. в Алатырском районе [36].

Места находок: государственный природный заповедник «Присурский», Алатырский район, кв. 32, на почве, сосняк лишайниково-зеленомошный, $56^{\circ} 59,915^{\prime}$ с.ш., $46^{\circ} 38,094^{\prime}$ в.д., 06.06.2010 г. (рис. 1).

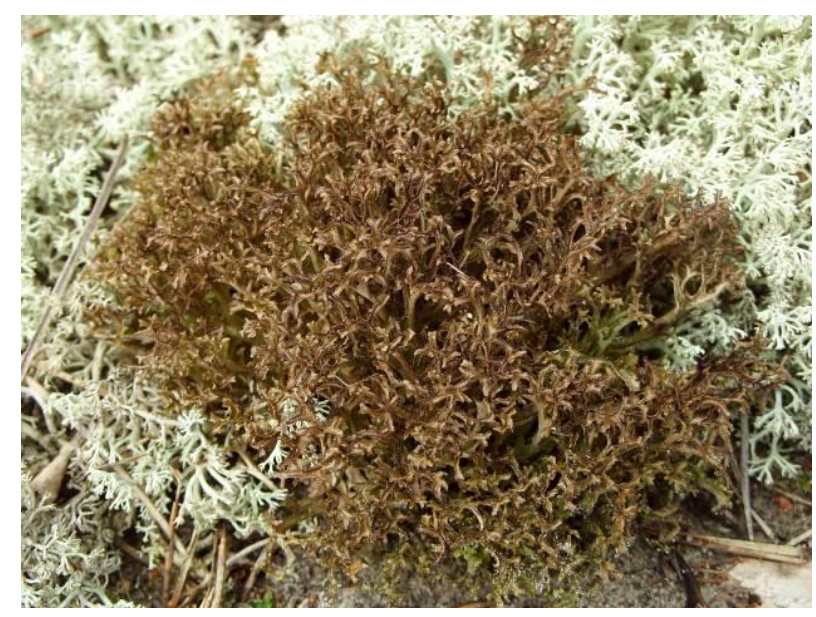

Рисунок 1 - Эпигейный реликтовый лишайник Cetraria ericetorum

Цетрария вересковая произрастает в сообществе эпигейных листоватых и кустистых лишайников Peltigera malacea (Ach.) Funck, P. rufescens (Weiss) Humb., Cladonia rangiferina (L.) Weber ex F.H. Wigg. Среднее проективное покрытие Cetraria ericetorum составляет около 50-60\% на $1 \mathrm{M}^{2}$. 
Cetrelia olivetorum (Nyl.) W. Culb. et C. Culb. редкий для Чувашской Республики и для всей территории Приволжской возвышенности. Как редкий вид занесен в Красные книги Республики Марий Эл [34], Республики Татарстан [31], Республики Мордовия [35], Нижегородской области [31]. Вид ранее отмечался на коре дуба в четырёхъярусных сложных дубравах [37].

Места находок: государственный природный заповедник «Присурский», Алатырский район, кв. 43, на наклоненной Tilia cordata по склону оврага, липняк широкотравный, 5459,802' с.ш., 46²45,725' в.д., 05.08.2010 г.; кв. 65, на наклоненных липах в овраге, липняк еловый разнотравный, 5459,445' с.ш., 46²6,135' в.Д., 2014 г.; Алатырский район, кв. 34 Безднинского участкового лесничества, пойма р. Бездна, на коре старых наклоненных лип, липняк снытево-пролесниковый, $54^{\circ} 51,008^{\prime}$ с.ш., 46²48,919' в.Д., 14.10 .2012 г.; национальный парк «Чаваш вармане», Шемуршинский район, кв. 23 Баскакского участкового лесничества, по лесной дороге Кучеки - Баскаки, на наклоненной липе, березняк орляковый с елью, 5454,849' с.ш., $47^{\circ} 17,687^{\prime}$ в.д., 28.06 .2011 г.; кв. 88 Баскакского участкового лесничества, пойма р. Бездна, на наклоненных липах, липняк еловый снытево-пролесниковый, $54^{\circ} 50,572^{\prime}$ с.ш., $\quad 47^{\circ} 12,299^{\prime}$ в.Д., 22.10 .2011 г.; кв. 89 Баскакского участкового лесничества, пойма p. Бездна, на наклоненных липах, липняк еловый осоковолосистый, $54^{\circ} 50,501^{\prime}$ с.ш., $47^{\circ} 13,516^{\prime}$ в.Д., 05.05.2014 г.; Ибресинский район, в 4 км северозападнее от п. Буинск, кв. 221 Березовского участкового лесничества, на коре липы, липняк разнотравный, 55²12,189' с.ш., 4658,618' в.Д., 22.08.2018 г.

Вне поймы C. olivetorum произрастает в сообществе с видами рода Brachythecium, Hypnum pallescens (Hedw.) P. Beauv, Platygyrium repens (Brid.) Bruch et al., Sanionia uncinata (Hedw.) Loeske, Ptilidium pulcherrimum (G. Web.) Vain., а в условиях поймы - c влаголюбивыми видами мхов и лишайников. В местах обнаружения вид встречался 1-3 талломами в $\mathrm{g}_{1} \mathrm{~V}-\mathrm{g}_{2} \mathrm{~V}$ состояний на высоте $120-180 \mathrm{~cm}$ от земли. Размеры талломов колеблются от $3 \times 3 \mathrm{~cm}$ до $5 \times 7$ см. Все талломы с краевыми соралями (рис. 2).

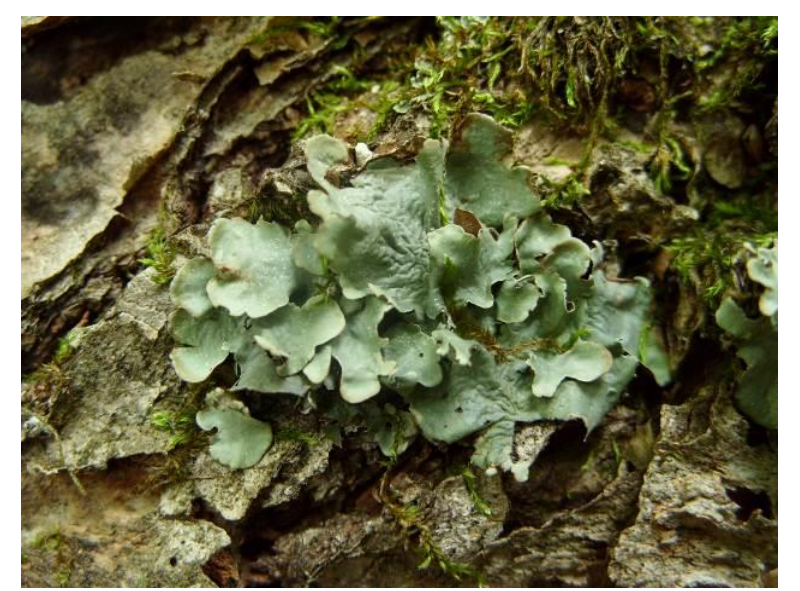

Рисунок 2 - Эпифитный лишайник Cetrelia olivetorum

Cresponea chloroconia (Tuck.) Egea et Torrente редкий вид для лихенофлоры Чувашской Республики и Приволжской возвышенности. Указан для республики Марий Эл [34], занесен в Красную книгу Республики Татарстан [31]. На территории Чувашии известен в окр. г. Чебоксары [38; 39]. Обнаружен на территории национального парка «Чаваш вармане» и государственного природного заповедника «Присурский».
Места находок: государственный природный заповедник «Присурский», Алатырский район, кв. 43, на наклоненной Tilia cordata по склону оврага, на коре Tilia cordata, липняк широкотравный, 5459,802' с.ш., $\quad 46^{\circ} 45,725^{\prime}$ в.д., $\quad 05.08 .2010$ г.; н национальный парк «Чаваш вармане», Шемуршинский район, кв. 88 Баскакского участкового лесничества, пойма р. Бездна, на коре Tilia cordata, липняк еловый разнотравный, 5450,583' с.ш., 47²12,269' в.д., 22.10.2011 г.

Cresponea chloroconia произрастает на липе диаметром 0,35 м, наклоненной под углом $85^{\circ}$ на север. Её талломы расположены среди других видов накипных лишайников - Arthonia byssacea (Weigel) Almq. и Opegrapha vulgata (Ach.) Ach. Все талломы с апотециями, молодые покрыты серовато-зеленоватым мучнистым налетом.

Evernia divaricata (L.) Ach. - новый вид для лихенофлоры Чувашской Республики. В соседних регионах известен из Нижегородской области [40], в Республике Марий Эл и Республике Мордовия [26; 27]. Как редкий вид занесен в Красные книги Республики Мордовия [32] и Нижегородской области [35].

Место находки: национальный парк «Чаваш вармане», Шемуршинский район, кв. 14 Баишевского участкового лесничества, близ кордона Кириллстан, пойма р. Бездна, на коре Tilia cordata, липняк черемухово-вязовый, $\quad 54^{\circ} 50,571^{\prime}$ с.ш., $\quad 47^{\circ} 12,228^{\prime}$ в.д., 21.10.2011 г.

Эверния растопыренная произрастает на прямых липах на высоте от 250 см и выше в сообществе с лишайниками Ramalina thrausta (Ach.) Nyl., Evernia prunastri, Flavoparmelia caperata (L.) Hale, Pachyphiale fagicola (Hepp) Zwackh. Всего было обнаружено несколько талломов в состоянии $\mathrm{g}_{1} \mathrm{v}$.

Heterodermia speciosa (Wulfen in Jacq.) Trevis. новый вид для лихенофлоры Чувашской Республики. В Приволжской возвышенности известен из территории Нижегородской области [40; 41], в Республике Марий Эл [26], Республике Мордовия [27] и Республике Татарстан [42]. Нами вид обнаружен в Шемуршинском (национальный парк «Чаваш вармане») и Алатырском районах. Как редкий вид гетеродермия занесена в Красные книги соседней Нижегородской области [35], Республики Татарстан [31], Республики Марий Эл [34], Республики Мордовия [32].

Место находки: национальный парк «Чаваш вармане», Шемуршинский район, кв. 88 Баскакского участкового лесничества, пойма р. Бездна, на коре Tilia cordata, липняк еловый звездчатково-осоко-снытевый с бересклетом, $54^{\circ} 50,571^{\prime}$ с.ш., 47²12,228' в.д., 21.10.2011 г.; кв. 89 Баскакского участкового лесничества, пойма р. Бездна, близ д. Мулинная, на наклоненных липах, липняк еловый разнотравный, 5450,528' с.ш., $47^{\circ} 13,734^{\prime}$ в.д., 10.10 .2013 г.; кв. 15 Баишевского участкового лесничества, на старой наклоненной липе, липняк разнотравный, $54^{\circ} 50,714^{\prime}$ с.ш., $47^{\circ} 10,040^{\prime}$ в.д., 24.10.2012 г.; Алатырский район, кв. 35 Безднинского участкового лесничества, пойма р. Бездна, на коре старых наклоненных лип, разнотравный,

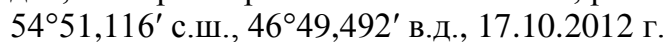

Heterodermia speciosa произрастает на липах, наклоненных под углом 70-75 (преимущественно на запад). Размеры талломов $3,5 \times 3$ см. Возрастное состояние $\mathrm{g}_{2} \mathrm{~V}$. H. speciosa растет на высоте $100 \mathrm{~cm}$ от земли в сообществе Lobarion pulmonariae Ochsner (1928). На коре среди мха обнаружены еще 12 особей в v1 и v2 состоянии. 
Leptogium cyanescens (Rabenh.) Körb. - новый вид для лихенофлоры Чувашской Республики и Приволжской возвышенности. Отмечен в Нижегородской области [42], Республике Марий Эл и Республике Мордовия [26; 27]. Находится близ южной границы распространения в Средней России. Занесен в Красную книгу Республики Мордовия [32].

Места находок: Алатырский район, кв. 34 Безднинского участкового лесничества, пойма р. Бездна, на коре старых наклоненных лип, липняк снытевопролесниковый, $\quad 54^{\circ} 51,008^{\prime}$ с.ш., $\quad$ 46² 48,919' в.д., 10.06.2013 г.; национальный парк «Чаваш вармане», Шемуршинский район, кв. 13 Баишевского участкового лесничества, пойма р. Бездна, на липе, липняк пролесниково-снытевый вдоль стариц, 5450,677' с.ш., 47010,667' в.д., 07.07.2011 г.; кв. 12 Баишевского участкового лесничества, пойма р. Бездна, на липе,

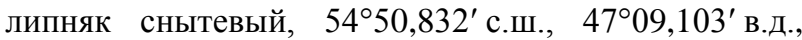
25.06.2013 г.; кв. 88 Баскакского участкового лесничества, пойма р. Бездна, на липе, липняк еловый звездчатково-осоко-снытевый с бересклетом, 54 50,571' с.ш., $47^{\circ} 12,228^{\prime}$ в.д., 21.10.2011 г.; на липе, липняк еловый разнотравный, $54^{\circ} 50,583^{\prime}$ с.ш., 47 $12,269^{\prime}$ в.д., 22.10 .2011 г.; кв. 88 Баскакского участкового лесничества, пойма р. Бездна, на наклоненных липах, липняк еловый снытево-пролесниковый, $54^{\circ} 50,572^{\prime}$ с.ш., 47²12,299' в.д., 22.10 .2011 г.; кв. 89 Баскакского участкового лесничества, пойма р. Бездна, близ д. Мулинная, на наклоненных липах, липняк осоковый с кленом в подросте, $54^{\circ} 50,735^{\prime}$ с.ш., 47²13,987' в.д., 04.07.2011 г.; на наклоненных липах, липняк еловый разнотравный, $54^{\circ} 50,528^{\prime}$ с.ш., $47^{\circ} 13,734^{\prime}$ в.д., 10.10.2013 г.

Вид произрастает у основания лип, часто с прикомлевыми мхами Barbula unguiculata Hedw., Homalia trichomanoides (Hedw.) Bruch et Schimp., Pseudoleskeella nervosa (Brid.) Nyholm, Radula complanata (L.) Dumort. реже к ним добавляются Anomodon viticulosus (Hedw.) Hook. et Tayl., Bryum laevifilum Syed, Zigodon sibiricus Ignatov, Ignatova, Iwats. et Tan. Ha наклонных липах лептогиум поднимается по стволу на высоту до 1,5 м и растет среди эпифитных мхов Leucodon sciuroides (Hedw.) Schwaer., Neckera pennata Hedw., Platygyrium repens, Pylaisia polyantha (Hedw.) Bruch et al.

Leptogium cyanescens хорошо размножается вегетативно с помощью изидий. Размеры талломов варьируют в зависимости от возрастного состояния, которые представлены от im (имматурного) до $\mathrm{g}_{3} \mathrm{~V}$ (старого, потенциально генеративного) состояний.

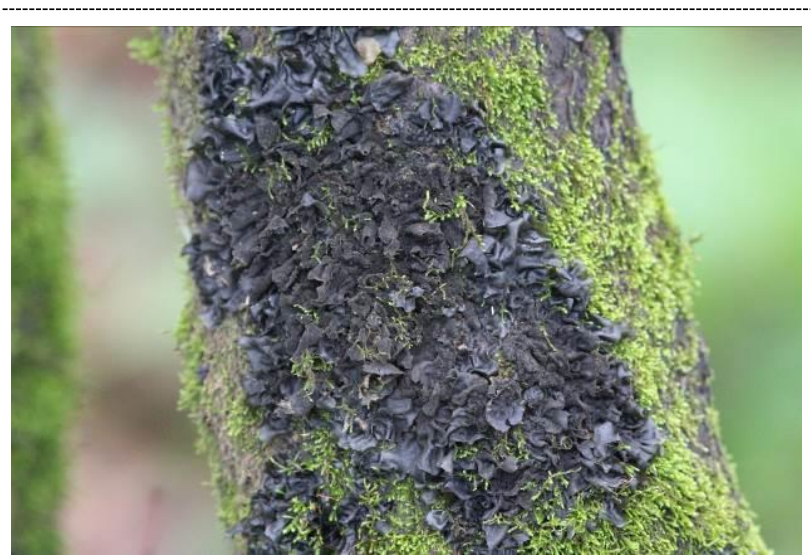

Рисунок 3 - Эпифитный лишайник Leptogium cyanescens
Leptogium saturninum (Dicks.) Nyl. - новый вид для лихенофлоры Чувашской Республики. Отмечен в Республике Марий Эл и Нижегородской области [26; 43]. Как редкий вид занесен в Красную книгу Нижегородской области [35].

Места находок: Шемуршинский район, кв. 14 Баишевского участкового лесничества, на коре Tilia cordata, липняк разнотравный, 5450,648' с.ш., 47²12,161' в.д., $\quad 29.10 .2015$ г.; кв. 89 Баскакского участкого лесничества, на липе, липняк снытевый, 5450,690' с.ш., 47¹3,848' в.д., 16.10.2019 г.

Lobaria pulmonaria (L.) Hoffm. - редкий вид для лихенофлоры Чувашской Республики. Ранее собран в Алатырском и Шумерлинском районах, по данным гербария Ботанического института Российской академии наук [44]. В соседних регионах встречается в Республике Марий Эл [45; 46], Республике Мордовия [47; 48], Республике Татарстан [44], в Нижегородской [49] и Ульяновской областях [50]. Как редкий и уязвимый вид лобария легочная занесен в Красные книги Российской Федерации [44], Республики Марий Эл [34], Ульяновской области [50], Республики Татарстан [31], Республики Мордовия [32], Нижегородской области [35].

На территории Чувашии вид обнаружен в Чебоксарском районе на территории государственного природного заказника «Заволжский» [28; 29], в Алатырском, Шемуршинском районах.

Места находок: национальный парк «Чаваш вармане», Шемуршинский район, кв. 88 Баскакского участкового лесничества, пойма р. Бездна, на коре Tilia cordata, липняк еловый звездчатково-осоко-снытевый с бересклетом, 5450,571' с.ш., 47¹2,228' в.Д., 21.10.2011 г; национальный парк «Чаваш вармане», Шемуршинский район, кв. 88 Баскакского участкового лесничества, пойма р. Бездна, на коре Tilia cordata, липняк еловый разнотравный, 5450,583' с.ш., 47¹2,269' в.д., 22.10.2011 г; кв. 15 Баишевского участкового лесничества, на одинокой липе, липняк разнотравный,

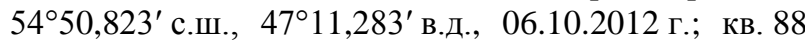
Баскакского участкового лесничества, пойма р. Бездна, на липе, липняк еловый разнотравный, $54^{\circ} 50,583^{\prime}$ с.ш., $47^{\circ} 12,269^{\prime}$ в.Д., 01.09.2013 г.; кв. 54, выдел 3 Баишевского участкового лесничества, пойма p. Черная Бездна, осиново-липовый лес, 05.11.2011 г., А.А. Яковлев; Алатырский район, кв. 34 Безднинского участкового лесничества, пойма р. Бездна, на коре старых наклоненных лип, липняк снытево-пролесниковый, 5451,008' с.ш., 46²48,919' в.Д., 14.10.2012 г.; Алатырский район, государственный природных заповедник «Присурский», кв. 65, на наклоненной липе, липняк осоко-волосистый, 5459,293' с.ш., $46^{\circ} 46,010^{\prime}$ в.Д., 04.10.2014 г.

В первом местонахождении Lobaria pulmonaria произрастает на липе мелколистной, наклоненной под углом $75^{\circ}$ на запад, имеет значительное проективное покрытие в виде скопления талломов диаметром $0,35 \mathrm{~m}^{2}$. Один из талломов размером $25 \times 27 \mathrm{~cm}$ растет на высоте 190-200 см от земли, в сообществе с лишайниками Amandinea punctata (Hoffm.) Coppins et Scheid., Anisomeridium biforme (Borrer) R.C. Harris, Bacidia rubella (Hoffm.) A. Massal., Cladonia chlorophaea (Flörke ex Sommerf.) Spreng., C. coniocraea 
(Flörke) Spreng., Coenogonium pineti (Ach.) Lücking et Lumbsch, Hypogymnia physodes (L.) Nyl., Lepraria incana (L.) Ach., Leptogium cyanescens, Opegrapha vulgata, Phaeophyscia ciliata (Hoffm.) Moberg, Phlyctis argena (Spreng.) Flot., Physconia detersa (Nyl.) Poelt, Peltigera praetextata (Flörke ex Sommerf.) Zopf, P. polydactyla (Neck.) Hoffm., Pertusaria amara (Ach.) Nyl., Ramalina farinacea (L.) Ach., Heterodermia speciosa, Scytinium teretiusculum (Wallr.) Otálora, P.M. Jørg. et Wedin и мхами Anomodon viticulosus, Ceratodon purpureus (Hedw.) Brid, Homalia trichomanoides, Hypnum pallescens, Pseudoleskeella nervosa, Leucodon sciuroides, Neckera pennata, Orthodicranum montanum (Hedw.) Loeske, Platygyrium repens, Pylaisia polyantha, Radula complanata. Второй таллом диаметром $10 \times 15$ см растет на высоте $350 \mathrm{~cm}$. Возрастное состояние упомянутых экземпляров $\mathrm{g}_{2} \mathrm{~V}$ (средневозрастное потенциально генеративное). Лобария успешно размножается вегетативно, между двумя более крупными особями среди мха Pseudoleskeella nervosa произрастают 11 особей в виргинильном $\left(\mathrm{v}_{1}\right)$ состоянии.

Во втором местонахождении отмечены два крупных таллома Lobaria pulmonaria на липе сердцелистной диаметром 0,34 м, наклоненной под углом $85^{\circ}$ на север. Первый таллом размером $15 \times 15$ см растет на высоте 175 см от земли. Остальные 12 талломов растут на высоте до $650 \mathrm{~cm}$. На стволе вместе с лобарией произрастают лишайники Acrocordia gemmata (Ach.) A. Massal., Anisomeridium biforme, Arthonia byssacea, Bacidia rubella, Coenogonium pineti, Cetrelia olivetorum, Cresponea chloroconia, Lepraria incana, Nephroma parile (Ach.) Ach., Opegrapha vulgata, Phlyctis argena, Pertusaria amara, Ramalina farinacea, $R$. pollinaria (Westr.) Ach. и мхи Anomodon viticulosus, Barbula unguiculata Hedw., Homalia trichomanoides, Pseudoleskeella nervosa, Neckera pennata, Zigodon sibiricus, Platygyrium repens, Pylaisia polyantha, Radula complanata. Возрастное состояние талломов $-\mathrm{g}_{1} \mathrm{~V}$ и $\mathrm{g}_{2} \mathrm{~V}$.

Лобария успешно размножается вегетативно. Между нижним и верхним слоевищами обнаружено еще около 20 особей в виргинильном ( $\mathrm{v}_{1}$ и $\left.\mathrm{v}_{2}\right)$ состоянии. Близ второго участка, в этом же квартале, в пойменном липняке обнаружено еще 14 деревьев липы с Lobaria pulmonaria.

На территории Алатырского района лобария встречается реже, чем в Шемуршинском районе. Так, в окр. д. Новиковка, лобария произрастает на старых липах диаметром 50-70 см на высоте от 90 до 400 см. На территории заповедника обнаружено только одно дерево с несколькими талломами размером $2 \times 3,5 \mathrm{~cm}$ и около 7 талломов в состоянии $\mathrm{g}_{1} \mathrm{~V}$.

Nephroma parile (Ach.) Ach. - новый вид для лихенофлоры Чувашской Республики. В Приволжской возвышенности известен с территории Нижегородской области, из Арзамасского района и окрестностей Нижнего Новгорода [49]. Как редкий вид занесена в Красную книгу Нижегородской области [35].

Место находки: Национальный парк «Чаваш вармане», Шемуршинский район, на коре Tilia cordata, липняк еловый разнотравный, 5450,583' с.ш., $47^{\circ} 12,269^{\prime}$ в.Д., 22.10 .2011 г.
Вид произрастает на коре наклонных лип в сообществе с другими видами влаголюбивых лишайников и мхов. Обнаружены три таллома размером $2,5 \times 3 \mathrm{~cm}$. Возрастное состояние $\mathrm{g}_{2} \mathrm{~V}$.

Scytinium subtile (Schrad.) Otálora, P.M. Jørg. et Wedin [Leptogium subtile (Schrad.) Torss] - новый вид для лихенофлоры Чувашской Республики и Приволжской возвышенности. Как редкий вид занесен в Красную книгу Республики Марий Эл [34], в 2013 г. отмечен в Мордовском заповеднике (Республика Мордовия) [27].

Места находок: Национальный парк «Чаваш вармане», Шемуршинский район, кв. 88 Баскакского участкового лесничества, пойма p. Бездна, на коре Tilia cordata, липняк еловый звездчатково-осокоснытевый с бересклетом, на липе, липняк еловый звездчатково-осоко-снытевый с бересклетом, 5450,571' с.ш., $47^{\circ} 12,228^{\prime}$ в.д., 21.10.2011 г.

Сцитиниум растает на старых, замшелых стволах липы, на мхах, на валеже, является эпибриофитом. Размножается половым путем при помощи аскоспор.

Scytinium tenuissimum (Hoffm.) Otálora, P.M. Jørg. \& Wedin [Leptogium tenuissimum (Hoffm.) Körb.] новый вид для лихенофлоры Чувашской Республики. Встречается в Республике Марий Эл и Мордовия [26; 27]. Как редкий вид занесен в Красную книгу Республики Марий Эл [34], в список редких и уязвимых видов растений и грибов Республики Мордовия [32].

Место находки: Национальный парк «Чаваш вармане», Шемуршинский район, кв. 88 Баскакского участкового лесничества, пойма р. Бездна, на валеже, липняк еловый пролесниково-снытевый, 54 $50,281^{\prime}$ с.ш., $47^{\circ} 13,976^{\prime}$ в.д., 03.11.2015 г.

Сцитиниум наитончайший был обнаружен на валеже среди влаголюбивых мхов и лишайника Leptogium cyanescens.

Scytinium teretiusculum (Wallr.) Otálora, P.M. Jørg. et Wedin [Leptogium teretiusculum (Wallr.) Arnold] новый вид для лихенофлоры Чувашской Республики и Приволжской возвышенности. Как редкий вид занесен в Красную книгу Республики Марий Эл [34], в 2013 году отмечен в Мордовском заповеднике (Республика Мордовия) [27].

Места находок: Национальный парк «Чаваш вармане», Шемуршинский район, кв. 88 Баскакского участкового лесничества, пойма р. Бездна, на липе, липняк еловый звездчатково-осоко-снытевый с бересклетом, 5450,571' с.ш., $47^{\circ} 12,228^{\prime}$ в.д., 21.10 .2011 г.; на липе, липняк еловый разнотравный, $54^{\circ} 50,583^{\prime}$ с.ш., $47^{\circ} 12,269^{\prime}$ в.Д., 22.10 .2011 г.

Вид приурочен к краям трещин коры наклоненных лип. Во всех сборах найден рядом или среди талломов Leptogium cyanescens совместно с накипными лишайниками открытых участков коры, лишенных мохового покрова (Acrocordia gemmata, Coenogonium pineti). По нашим наблюдениям, эпифитные мхи препятствуют развитию мелких талломов этого лишайника, быстро вытесняют его, захватывая свободный субстрат.

Ramalina thrausta (Ach.) Nyl. - редкий вид для лихенофлоры Чувашской Республики. В Приволжской возвышенности обнаружен в Верхнеуслонском районе Республики Татарстан [51] и Арзамасском 
Синичкин Е.А., Богданов Г.А., Димитриев А.В.

районе Нижегородской области [40; 41]. Вид занесен в Красные книги Республики Марий Эл [30], Республики Татарстан [31], Нижегородской области [35]. В Чувашии обнаружен в Яльчикском районе в окр. д. Яманчурино [12; 14].

Места находок: национальный парк «Чаваш вармане», Шемуршинский район, кв. 14 Баишевского участкового лесничества, близ кордона Кириллстан, пойма р. Бездна, на липе, липняк черемухово-вязо-

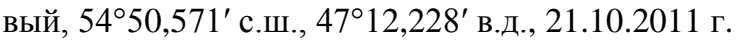

$R$. thrausta обнаружена на прямых липах и растет среди Evernia prunastri, Flavoparmelia caperata, Melanelixia subargentifera (Nyl.) O. Blanco et al., Pachyphiale fagicola, Hypogymnia tubulosa и мхами Platygyrium repens, Ptilidium pulcherrimum на высоте $300 \mathrm{~cm}$. Всего обнаружено 4 таллома длиной от 2 до $7 \mathrm{~cm}$. Возрастное состояние $\mathrm{g}_{1} \mathrm{~V}-\mathrm{g}_{2} \mathrm{~V}$. Все экземпляры с верхушечными соралиями.

Ramalina sinensis Jatta - новый вид для лихенофлоры Чувашской Республики и Приволжской возвышенности. В соседней Нижегородской области указывается для Ветлужского района [49]. Занесен в Красную книгу Республики Марий Эл [34].

Места находок: национальный парк «Чаваш вармане», Шемуршинский район, кв. 88 Баскакского участкового лесничества, на берегу р. Бездна, на Populus tremula L., осинник разнотравный, 54 $50,433^{\prime}$ с.Ш., 47²13,086' в.Д., 22.10 .2011 г.

$R$. sinensis встречена на стволе двух осин диаметром 25-28 см. Вид произрастает на высоте 120 см от земли в сообществе с лишайниками Lecanora allophana Nyl., Physcia aipolia (Ehrh. ex Humb.) Fürnr., Ramalina farinacea и эпифитным мхом Orthotrichum obtusifolium Brid. Всего обнаружено 3 таллома от 3 до 5 см длиной. Возрастное состояние $-\mathrm{g}_{1}$ и $\mathrm{g}_{2}$. Все особи с апотециями.

Xanthomendoza ulophyllodes (Räsänen) Søchting, Kärnefelt et S.Y. Kondr. [Xanthoria ulophyllodes Räsänen] - редкий вид для лихенофлоры Чувашской Республики и Приволжской возвышенности. На территории республики известен из 4 мест: из Чебоксарского района [38; 39], Яльчикского района [12; 14], национального парка «Чаваш вармане» (Шемуршинский район), государственного природного заповедника «Присурский» (Алатырский район).

Место находки: государственный природный заповедник «Присурский», Алатырский район, кв. 20, на коре Populus tremula, осинник еловый с березой и рябиной, 54 $59,864^{\prime}$ с.ш., $46^{\circ} 43,644^{\prime}$ в.Д., 14.07 .2011 г.; национальный парк «Чаваш вармане», Шемуршинский район, близ кордона Кириллстан, пойма р. Бездна, на коре Padus avium Mill., липняк черемухововязовый, $54^{\circ} 50,571^{\prime}$ с.ш., 47²12,228' в.д., 21.10.2011 г.

В данных местообитаниях обнаружено около 15 талломов площадью от $1 \times 1,5 \mathrm{~cm}^{2}$ до $3,5 \times 5 \mathrm{~cm}^{2}$ на высоте $80-180$ см от земли. Все образцы с соредиями. Возрастное состояние особей $\mathrm{g}_{1} \mathrm{~V}-\mathrm{g}_{2} \mathrm{~V}$.

Usnea dasopoga (Ach) Nyl. - редкий вид для лихенофлоры Чувашской Республики. В соседних регионах встречается в Нижегородской области [40], Республике Татарстан [52], Республике Марий Эл [26], Республике Мордовия [27; 47]. В Чувашии известен из Заволжья [28; 29]. Как редкий вид занесен в Красные книги Республики Мордовия [32] и Республики Татарстан [31].

Места находок: государственный природный заповедник «Присурский», Алатырский район, окр. с. Атрать, кв. 98, на ветке Betula pendula Roth, березняк разнотравный, $54^{\circ} 58,949^{\prime}$ с.ш., $46^{\circ} 39,777^{\prime}$ в.д., 25.10.2010 г.; национальный парк «Чаваш вармане», Шемуршинский район, кв. 78 Баскакского участкового лесничества, на ветках ели европейской, ельник зеле-

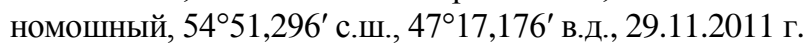

Usnea florida (L.) Weber ex F.H. Wigg. - новый вид для лихенофлоры Чувашской Республики. В соседних регионах встречен в Республике Марий Эл [26; 45; 53], Республике Мордовия [27]. Занесен в Красные книги Российской Федерации [44], Республики Мордовия [32], Республики Марий Эл [34].

Место находки: государственный природный заповедник «Присурский», Алатырский район, окр. с. Атрать, кв. 35, на ветке Tilia cordata, липняк разнотравный, 5459,441' с.ш., 46³9,734' в.д., 18.08 .2010 г.

В данном местообитании обнаружен 1 таллом длиной 1 см виргинильного состояния (v2) без апотеций с мелкобородавчатыми сосочками.

Usnea subfloridana Stirt. - редкий вид для лихенофлоры Чувашской Республики. Встречается в Нижегородской области, республиках Марий Эл, Татарстан, Мордовия. На территории Чувашии обнаружен в Чебоксарском районе [28; 29]. Как редкий вид занесен в Красную книгу Республики Мордовия [32].

Места находок: государственный природный заповедник «Присурский», Алатырский район, окр. с. Атрать, кв. 98, на ветке Betula pendula, березняк разнотравный, 5458,949' с.ш., 46³9,777' в.д., 25.10 .2010 г.; национальный парк «Чаваш вармане», Шемуршинский район, кв. 78 Баскакского участкового лесничества, на ветках Picea abies, ельник зеленомошный, 54ํ51,296' с.ш., $47^{\circ} 17,176^{\prime}$ в.д., 29.11.2011 г.

На территории заповедника Usnea subfloridana обнаружена на ветке березы в сообществе лишайников Parmelia sulcata, Hypogimnia physodes, Usnea dasopoga. В национальном парке «Чаваш вармане» встречены 4 таллома 4-6 см длиной. Жизненное состояние обнаруженных особей - g2v.

\section{Выводы}

На территории Чувашского Присурья выявлено 20 новых и редких видах лишайников, из них 10 видов являются новыми для Чувашской Республики, 5 видов - новые для Приволжской возвышенности.

На территории национального парка «Чаваш вармане» отмечено 18 видов (Bryoria nadvornikiana, Br. trichodes, Cetrelia olivetorum, Cresponea chloroconia, Evernia divaricata, Heterodermia speciosa, Leptogium cyanescens, L. saturninum, Lobaria pulmonaria, Nephroma parile, Scytinium tenuissimum, Sc. subtile, Sc. teretiusculum, Usnea dasopoga, U. subfloridana, Ramalina thrausta, Ramalina sinensis, Xanthomendoza ulophyllodes), на территории государственного природного заповедника «Присурский» -8 видов (Cetraria ericetorum, Cetrelia olivetorum, Cresponea chloroconia, Lobaria pulmonaria, Usnea dasopoga, U. subfloridana, U. florida, Xanthomendoza ulophyllodes).

18 лишайников (Bryoria nadvornikiana, Br. trichodes, Cetrelia olivetorum, Cresponea chloroconia, Ever- 
nia divaricata, Heterodermia speciosa, L. cyanescens, Leptogium saturninum, Nephroma parile, Scytinium subtile, Sc. teretiusculum, Sc. tenuissimum, Usnea dasopoga, Us.florida, Us. subfloridana, Ramalina thrausta, R. sinensis, Xanthomendoza ulophyllodes) предложены в новое издание Красной книги Чувашской Республики со статусом III - редкие виды. 2 вида лишайников (Cetraria ericetorum Lobaria pulmonaria) отнесены к категории II - уязвимые виды, сокращающиеся в численности.

\section{Список литературы:}

1. Папченков В.Г., Димитриев А.В. О природном районировании Чувашской Республики // Экологический вестник Чувашской Республики. 1993. Вып. 2. C. $77-84$.

2. Плетнева-Соколова А.Д. Растительный покров Чувашской АССР // Чувашская АССР: очерки о природе. Чебоксары: Чувашгосиздат, 1952. С. 74-112.

3. Физико-географическое районирование Среднего Поволжья / под ред. А.В. Ступишина. Казань: Изд-во Казанского ун-та, 1964. 198 с.

4. Гафурова М.М. О ботанико-географическом районировании Чувашии // Изучение и охрана флоры Средней России: материалы VII науч. совещ. по флоре Средней России (Курск, 29-30 янв. 2011 г.) / под ред. В.С. Новикова, С.Р. Майорова и А.В. Щербакова. М.: Изд-во Ботанического сада МГУ, 2011. С. $50-55$.

5. Особо охраняемые природные территории Чувашской Республики: материалы к единому пакету кадастровых сведений. Чебоксары: ГУП «ИПК «Чувашия», 2004. 444 с.

6. Особо охраняемые природные территории Чувашской Республики: материалы к единому пакету кадастровых сведений. Чебоксары: ГУП «ИПК «Чувашия», 2012. 424 с.

7. О создании особо охраняемых природных территорий регионального значения: постановление кабинета министров Чувашской Республики от 29 декабря 2017 г. № 552 [Электронный ресурс] // Портал «Гарант». - https://base.garant.ru/42544952.

8. Синичкин Е.А., Богданов Г.А., Омельченко П.Н. Редкие и исчезающие лишайники Чувашской Республики, нуждающиеся в охране // Раритеты флоры Волжского бассейна: докл. участников II Российской науч. конф. Тольятти: Кассандра, 2012. С. 230-230.

9. Синичкин Е.А., Богданов Г.А., Омельченко П.Н. Предварительные итоги изучения лихенофлоры Чувашской Республики // Тез. докл. II (X) междунар. ботанической конф. молодых ученых в СанктПетербурге 11-16 ноября 2012 года. СПб.: СПбГЭТУ «ЛЭТИ», 2012. С. 43-44.

10. Синичкин Е.А., Богданов Г.А., Димитриев А.В., Семенова И.И., Омельченко П.Н. К изучению лишайников лесостепной зоны Чувашской Республики // Вестник Волжского университета им. В.Н. Татищева. 2013. Т. 1, № 4 (14). С. 46-57.

11. Синичкин Е.А., Богданов Г.А., Омельченко П.Н. Предварительные итоги изучения лихенофлоры заповедника «Присурский» и национального парка «Чаваш Вармане» // Современная ботаника в России. Тр. ХІІІ съезда РБО и конфер. «Научные основы охраны и рационального использования растительного покрова Волжского бассейна». Т. 1: Эмбриология. Структурная ботаника. Альгология. Микология. Лихенология. Бриология. Палеоботаника. Биосистематика. Тольятти: Кассандра, 2013. С. 209-210.

12. Синичкин Е.А., Богданов Г.А., Омельченко П.Н., Чумбакова Т.Е. К изучению лихенофлоры памятника природы «Шемалаковский ландшафт» (Чувашская Республика) // Превентивная экология: современные проблемы устойчивого развития территорий: мат-лы 2-х междунар. науч.-практ. конф. Чебоксары: Типография «Новое время», 2012. С. 84-86.

13. Синичкин Е.А., Богданов Г.А., Омельченко П.Н. O предварительных итогах изучения лишайников государственного природного заповедника «Присурский» (Чувашская Республика, Россия) // Актуальные проблемы изучения и сохранения фито- и микобиоты $=$ Modern problems in botanical and mycological research: сб. ст. II междунар. науч.-практ. конф., Минск, 12-14 ноября 2013 г. Мн.: Изд. центр БГУ, 2013. С. 113-114.

14. Синичкин Е.А., Богданов Г.А., Омельченко П.Н. Эколого-субстратный анализ лишайников памятника природы «Шемалаковский ландшафт» (Чувашская Республика) // Научные труды Государственного природного заповедника «Присурский». 2015. Т. 30, № 1. С. 229-233.

15. Синичкин Е.А., Семенова И.И. Дополнительные материалы по изучению эпифитной лихенофлоры заповедника «Присурский» // Научные труды Государственного природного заповедника «Присурский». 2010. Т. 24. С. 125-127.

16. Синичкин Е.А., Семенова И.И., Акбердина Р.Х. Анализ эпифитной лихенофлоры заповедника «Присурский» // Научные исследования как основа охраны природных комплексов заповедников и заказников: сб. мат-лов всерос. науч.-практ. конф., 29 октября 2009 г. Киров: ООО «Типография «Старая Вятка», 2009. C. 138-140.

17. Синичкин Е.А., Семенова И.И., Акбердина Р.Х. Материалы к изучению эпифитной лихенофлоры заповедника «Присурский» // Труды Государственного природного заповедника «Присурский». 2009. Т. 22. C. $83-84$.

18. О внесении изменений в некоторые постановления Правительства Чувашской Республики: постановление кабинета министров Чувашской Республики от 24.12.2009 г. № 414 [Электронный ресурс] // Портал «Гарант». - https://base.garant.ru/17685161.

19. Окснер А.Н. Определитель лишайников СССР. Морфология, систематика, географическое распространение. Вып. 2. Л.: Наука, 1973. 283 с.

20. Флора лишайников России: биология, экология, разнообразие, распространение и методы изучения лишайников / отв. ред. М.П. Андреев, Д.Е. Гимельбрант. М., СПб.: Товарищество научных изданий КМК, 2014. 392 с.

21. Михайлова И.Н., Воробейчик Е.Л. Размерная и возрастная структура популяций эпифитного лишайника Hypogymnia physodes (L.) Nyl. в условиях атмосферного загрязнения // Экология. 1999. № 2. C. $130-137$.

22. Суетина Ю.Г. Онтогенез и структура популяции Xanthoria parietina (L.) Th. Fr. в различных эко- 
логических условиях // Экология. 2001. № 3. С. 203208.

23. Михайлова И.Н. Анализ субпопуляционных структур эпифитных лишайников (на примере Lobaria pulmonaria (L.) Hoffm.) // Вестник Нижегородского университета им. Н.И. Лобачева. 2005. № 1. Вып. 9. C. $124-134$.

24. Список лихенофлоры России. СПб.: Наука, 2010. 194 c.

25. Esslinger T.L. A cumulative checklist for the lichen-forming, lichenicolous and allied fungi of the continental United States and Canada. Fargo, North Dakota: North Dakota State University, 2019. Ver. 23. https://ndsu.edu/pubweb/ esslinge/chcklst/chcklst7.htm.

26. Богданов Г.А. Аннотированный список лишайников заповедника // Научные труды Государственного природного заповедника «Большая Кокшага». 2015. Вып. 7. С. 206-244.

27. Урбанавичене И.Н., Урбанавичюс Г.П. Лихенофлора Мордовского заповедника (аннотированный список видов) // Флора и фауна заповедников. 2016. Вып. 126. 41 с.

28. Синичкин Е.А., Богданов Г.А., Димитриев А.В., Семенова И.И., Омельченко П.Н. О новых и редких видах лишайников из лесных районов Заволжья Чувашской Республики // Вестник Волжского университета им. В.Н. Татищева. 2013. Т. 1, № 4 (14). С. 58-63.

29. Синичкин Е.А., Богданов Г.А., Димитриев А.В., Смирнова Н.В., Омельченко П.Н. К изучению лишайников государственного природного заказника «Заволжский» (Чувашская Республика) // Самарский научный вестник. 2018. Т. 7, № 4 (25). С. 108-115.

30. Инсарова И.Д., Инсаров Г.Э. Сравнительные оценки чувствительности эпифитных лишайников различных видов к загрязнению // Проблемы экологического мониторинга и моделирования экосистем. Т. 12. Л.: Гидрометиздат, 1989. С. 132-174.

31. Красная книга Республики Татарстан: животные, растения, грибы. Изд. 3-е. Казань: Идеал-пресс, 2016. 759 c.

32. Красная книга Республики Мордовия: в 2 т. Т. 1: Редкие виды растений и грибов. Изд. 2-е, перераб. Саранск: Изд-во Мордов. ун-та, 2017. 409 с.

33. Шустов М.В. Таксономический состав флоры лишайников Приволжской возвышенности // Естественно-научные исследования в Симбирско-Ульяновском крае на рубеже веков. Ульяновск: ГУП «Печатный двор», 1999. С. 39-50.

34. Красная книга Республики Марий Эл. Том «Растения. Грибы». Йошкар-Ола: МарГУ, 2013. 324 с.

35. Красная книга Нижегородской области. Т. 2: Сосудистые растения, моховидные, водоросли, лишайники, грибы. Калининград: Издательский дом «РОСТ-ДОАФК», 2017. 304 с.

36. Шустов М.В. Лишайники Приволжской возвышенности. М.: Наука, 2006. 240 с.

37. Шустов М.В. Систематический список лишайников Приволжской возвышенности // Труды Ульяновского научного центра «Ноосферные знания и технологии» РАЕН, 1999. Вып. 2, т. 2. С. 35-55.

38. Синичкин Е.А., Богданов Г.А., Омельченко П.Н. К изучению лишайников окрестностей г. Чебоксары Чувашской Республики // Научные труды Государ- ственного природного заповедника «Присурский». 2014. T. 29. C. 41-46.

39. Синичкин Е.А., Богданов Г.А., Омельченко П.Н. Эколого-субстратный анализ лишайников окрестностей г. Чебоксары Чувашской Республики // Научные труды Чебоксарского филиала Главного ботанического сада им. Н.В. Цицина РАН. 2014. № 7. С. 90-96.

40. Урбанавичене И.Н., Урбанавичюс Г.П. Лишайники Керженского заповедника // Труды Государственного природного заповедника «Керженский»: Природные условия Керженского заповедника и некоторые аспекты охраны природы Нижегородской области. 2001. Т. 1. С. 149-171.

41. Шарапова М.Г., Урбанавичене И.Н., Урбанавичюс Г.П. Редкие виды лишайников Нижегородской области // Тез. VII молодежной конф. ботаников в Санкт-Петербурге. СПб.: Издательство: Буслай, 2000. C. 89.

42. Евстигнеева А.С. Аннотированный список лишайников Республики Татарстан // Новости систематики низших растений. 2007. Т. 41. С. 196-229.

43. Урбанавичене И.Н., Урбанавичюс Г.П. О лихенофлоре Керженского заповедника (Нижегородская область) // Новости систематики низших растений. 2001. Т. 35. С. 208-217.

44. Красная книга Российской Федерации (растения и грибы). М.: Товарищество научных изданий КМК, 2008. 855 с.

45. Васильков Б.П. К флоре лишайников Марийской республики // Сборник трудов Поволжского лесотехнического института им. М. Горького. 1940. № 3. С. 16-23.

46. Богданов Г.А. Распространение редких и исчезающих видов лишайников в Республике Марий Эл // Проблемы экологии и природопользования в бассейнах рек Республики Марий Эл и сопредельных регионов: сб. мат-лов межрегион. науч.-практ. конф. Йошкар-Ола, 2006. С. 27-31.

47. Кузнецов Н.И. Флора грибов, лишайников, мхов и сосудистых растений Мордовского заповедника // Труды Мордовского государственного заповедника. 1960. Вып. 1. С. 71-128.

48. Терешкина Л.В. Лобария легочная // Красная книга Республики Мордовия: Т. 1: Редкие виды растений, лишайников и грибов / сост. Т.Б. Силаева. Саранск: Мордов. кн. изд-во, 2003. С. 249.

49. Преснякова М.Г. Новые виды лишайников Нижегородской области // Новости систематики низших растений. 2001. Т. 35. С. 200-210.

50. Красная книга Ульяновской области. М.: Издательство «Бука Веди», 2015. 550 с.

51. Мережковский К.С. К познанию лишайников окрестностей Казани // Труды Ботанического музея Академии наук. 1920. Вып. 18. С. 93-142.

52. Малышева Н.В., Смирнов А.Г. Определитель лишайников Татарской АССР. Казань: Издательство Казанского университета, 1982. 148 с.

53. Богданов Г.А., Суетина Ю.Г. Экологическая приуроченность Usnea florida (L.) Weber ex F.H. Wigg. на территории Республики Марий Эл // Научные труды государственного природного заповедника «Большая Кокшага». 2007. Вып. 2. С. 219-229. 


\section{ECOLOGY AND DISTRIBUTION OF RARE LICHENS OF THE CHUVASH PRISURYE}

(C) 2020

Sinichkin Evgeny Arkadyevich, researcher

Cheboksary Branch of the Main Botanical Garden named after N.V. Tsitsin of the Russian Academy of Sciences (Cheboksary, Russian Federation)

Bogdanov Gennady Alekseevich, senior researcher

State Nature Reserve «Bolshaya Kokshaga» (Yoshkar-Ola, Russian Federation)

Dimitriev Aleksandr Veniaminovich, candidate of biological sciences, director

Cheboksary Branch of the Main Botanical Garden named after N.V. Tsitsin of the Russian Academy of Sciences (Cheboksary, Russian Federation)

Abstract. The paper contains data about 20 new and rare lichens of the Chuvash Prisurye. 10 lichens are new for the Chuvash Republic, 5 species are new for the Privolzhskaya Upland. The identified lichen species are indicators of old-growth, undisturbed and intact forests that have been preserved in specially protected natural areas. There are 18 species in the National Park "Chuvash varmane» and 8 species in the State Nature Reserve «Prisursky». Geographical coordinates, distribution features in neighboring regions, ecological-substrate and phytocenotic confinement and age status are indicated for each species. The information on the ecology and distribution of rare lichen species is updated. 18 species of lichens (Bryoria nadvornikiana, Br. trichodes, Cetrelia olivetorum, Cresponea chloroconia, Evernia divaricata, Heterodermia speciosa, Leptogium cyanescens, L. saturninum, Nephroma parile, Scytinium subtile, Sc. teretiusculum, Sc. tenuissimum, Usnea dasopoga, Us. florida, Us. subfloridana, Ramalina thrausta, $R$. sinensis, Xanthomendoza ulophyllodes) are proposed in the new edition of the Red book of the Chuvash Republic with the Status III - rare species. 2 lichen species (Cetraria ericetorum, Lobaria pulmonaria) are classified as category II-vulnerable species, declining in number.

Keywords: lichens; lichen flora; rare species; plant communities; forest; pine forests; linden forests; aspen forests; birch forests; area; Chuvash Prisurye; state nature reserve «Prisursky»; National Park «Chuvash varmane»; Alatyrsky District; Ibresinsky District; specially protected natural territory; Red book; Chuvash Republic.

$* * *$

УДК 574.2/474:502.31/35/37:504.05/062/75.06

DOI 10.24411/2309-4370-2020-11116

Статья поступила в редакцию 06.01.2020

\section{ЭКОЛОГИЧЕСКАЯ ОЦЕНКА САНИТАРНЫХ ПОКАЗАТЕЛЕЙ ДРЕВЕСНЫХ РАСТЕНИЙ В ПРИРОДНЫХ И ТЕХНОГЕННЫХ УСЛОВИЯХ}

(C) 2020

Сираева Ирина Салаватовна, аспирант кафедры ботаники и экологии

Саратовский национальный исследовательский государственный университет имени Н.Г. Чернышевского

(2. Саратов, Российская Федерация)

Ларионов Максим Викторович, доктор биологических наук, доцент, профессор кафедры биологии и экологии

Балашовский институт (филиал) Саратовского начионального исследовательского государственного университета имени Н.Г. Чернышевского (г. Балашов, Саратовская область, Российская Федерация)

Ларионов Николай Викторович, кандидат биологических наук, директор

Котельниковская средняя общеобразовательная школа № 2

(2. Котельники, Московская область, Российская Федерачия)

Солдатова Валерия Викторовна, аспирант кафедры ботаники и экологии

Громова Татьяна Сергеевна, аспирант кафедры ботаники и экологии

Ермоленко Анна Сергеевна, аспирант кафедры ботаники и экологии

Саратовский национальный исследовательский государственный университет имени Н.Г. Чернышевского

(2. Саратов, Российская Федерация)

Кулагина Екатерина Юрьевна, кандидат биологических наук, доцент кафедры биологии и экологии Владимирский государственный университет

имени Александра Григорьевича и Николая Григорьевича Столетовых (2. Владимир, Российская Федеращия)

Аннотация. Установлены и проанализированы показатели санитарного состояния древесных растений в условиях естественных и искусственных экосистем Воронежской и Саратовской областей. В пригородных экосистемах территории исследований состояние древесных растений определено на уровне слабой поврежденности. В пригородных районах к городу Балашову с наибольшим хозяйственно-техносферным потенциалом древесные растения достигают средней (умеренной) степени повреждений. В удаленных относительно сохранившихся экосистемах (контрольные данные) состояние этих организмов соответствует слабому эколого-диагностическому критерию. По выявленным средним арифметическим санитарным показателям в Воронежском регионе наилучшим состоянием характеризуются древесные растения в экосистемах Новохоперска и Грибановского, в Саратовском - в Турках и Самойловке. Также выявлены достоверные различия в средне- 